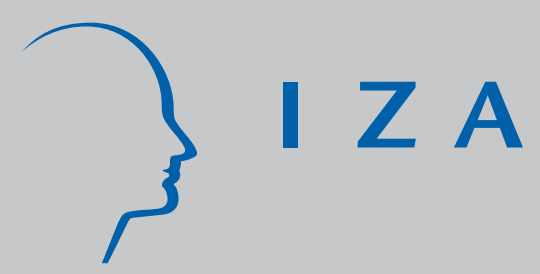

IZA DP No. 490

Social Security and Taxation of Labour Subject to Subsidiarity and Freedom of Movement

Wolfram F. Richter

May 2002 


\title{
Social Security and Taxation of Labour Subject to Subsidiarity and Freedom of Movement
}

\author{
Wolfram F. Richter \\ University of Dortmund \\ and IZA, Bonn
}

\author{
Discussion Paper No. 490 \\ May 2002
}

\author{
IZA \\ P.O. Box 7240 \\ D-53072 Bonn \\ Germany \\ Tel.: +49-228-3894-0 \\ Fax: +49-228-3894-210 \\ Email: iza@iza.org
}

This Discussion Paper is issued within the framework of IZA's research area Internationalization of Labor Markets. Any opinions expressed here are those of the author(s) and not those of the institute. Research disseminated by IZA may include views on policy, but the institute itself takes no institutional policy positions.

The Institute for the Study of Labor (IZA) in Bonn is a local and virtual international research center and a place of communication between science, politics and business. IZA is an independent, nonprofit limited liability company (Gesellschaft mit beschränkter Haftung) supported by the Deutsche Post AG. The center is associated with the University of Bonn and offers a stimulating research environment through its research networks, research support, and visitors and doctoral programs. IZA engages in (i) original and internationally competitive research in all fields of labor economics, (ii) development of policy concepts, and (iii) dissemination of research results and concepts to the interested public. The current research program deals with (1) mobility and flexibility of labor, (2) internationalization of labor markets, (3) welfare state and labor markets, (4) labor markets in transition countries, (5) the future of labor, (6) evaluation of labor market policies and projects and (7) general labor economics.

IZA Discussion Papers often represent preliminary work and are circulated to encourage discussion. Citation of such a paper should account for its provisional character. A revised version may be available on the IZA website (www.iza.org) or directly from the author. 
IZA Discussion Paper No. 490

May 2002

\section{ABSTRACT \\ Social Security and Taxation of Labour Subject to Subsidiarity and Freedom of Movement ${ }^{*}$}

In Europe, the competence for social security and the right to levy income tax lie with the country of employment in cross-border matters. This has two disadvantages. First, the Employment Principle distorts active persons' choice of place of work. Second, the employment-based regulation of state competencies cannot be applied to non-active persons. The Treaty of Maastricht, however, confers the right of free movement to all citizens of the Union. Against this background, this paper pleads for a reform in European policy coordination. The Employment Principle should be replaced with the Principle of Delayed Integration where cross-border matters are concerned.

JEL Classification: $\quad \mathrm{H} 21, \mathrm{H} 70, \mathrm{~J} 61$

Keywords: Social security and taxation of mobile labour, Employment Principle, Delayed Integration, Origin Principle, free movement

Wolfram Richter

LS VWL

University of Dortmund

44221 Dortmund

Germany

Tel.: +49 2317553146

Fax: +49231755 5404

Email: wolfram.richter@wiso.uni-dortmund.de

\footnotetext{
* I would like to thank John Hassler, Mats Persson and an anonymous referee for valuable comments on an earlier draft.
} 


\section{Introduction}

The European Union stands for the will to overcome the political and economical separation of its Member States. Europe should be a place where its citizens enjoy the freedom to move and to pursue their business wherever they wish. This goal was confirmed in the Treaty of Maastricht by the introduction of Union Citizenship. According to Article 18 every citizen of the Union shall have the right to move and reside freely. This was a confirmation of the policy of integration in as much as the right to free movement was and still is a privilege of active persons. Non-active persons such as the recipients of social assistance are effectively constrained in their choice of residence till this very day.

Not least of all political integration and free movement are expected to enhance economic development. However, it is precisely this expectation that is being questioned in connection with Eastern Enlargement. Whether or not, and to what extent, there will be undesirable migration in addition to desirable migration is something that is stirring emotions.

Even economists appear to be split as to how to judge Eastern Enlargement and what political measures to recommend. Some see the accession of new Member States as a welcome opportunity to break down rigid labour market structures with increased external competition (Burda, 2000). In their view, there is no such thing as undesirable migration. Others, on the other hand, are concerned about immigration that is driven simply by the desire to reap social benefits. They see testing times ahead for the welfare state (Sinn, 1994). Although Europeanwide harmonisation could certainly remove the basis for social tourism, such policy harmonisation is in conflict with the principle of subsidiarity, and due to the economic heterogeneity of the Member States it is not worth striving for, at least for the foreseeable future. Thus there seems to be a fundamental trade-off between the objective of free movement, on the one hand, and the objective of subsidiarity, on the other hand. The object of this paper is to analyse this trade-off and to discuss possible solutions.

What is being sought is a regulatory framework for European policy co-ordination that can do several things. First, it must put the Member States in a position in which they are able to pursue their own redistribution objectives in accordance with the subsidiarity principle. Second, it must treat all citizens of the Union equally with respect to their right to free movement. In particular, this means that active and non-active persons must no longer be 
treated differently. Third, this regulatory framework must be designed in such a way that it impedes undesirable migration without impeding desirable migration.

It is argued in this paper that the present EU framework fulfils such co-ordination requirements inadequately. It is employment-based, which means that the citizens of the Union are effectively subject to income taxation and social security in that Member State where they are employed ("lex loci laboris"). Such assignment of migrants is problematic for two major reasons. For one, an employment-based assignment cannot by nature be applied to non-active individuals and this makes a liberal application of the right to free movement difficult. For another, such a rule of assignment tends to distort decisions on migration due to the fact that the choice of place of work has an immediate effect on taxes and social benefits. From an empirical point of view it is not fully clear how important such distortions are. Still economic theory suggests not to play them down and rather to eliminate them if possible. That however requires to replace the Principle of (the Country of) Employment by something different. The alternative on which this paper focuses is the so-called Principle of Delayed Integration. Delayed Integration means that migrants - active persons and non-active ones alike- remain assigned to their country of origin for tax and social security purposes for an agreed period of time after emigrating. Only after this period has elapsed does the country of immigration take over the fiscal competence for these particular persons.

This concept of Delayed Integration is not completely novel. It is already put into practice here and there in international tax and social security law. Its systematic application in international policy co-ordination however, has only recently attracted particular attention (Sakslin, 1997; Richter, 2001b; Weichenrieder, 2000). The Council of Economic Advisors to the German Ministry of Finance (Wissenschaftlicher Beirat, 2001) has looked into Delayed Integration in detail in its report on "Free Movement and Social Security in Europe". After weighing up the advantages and the disadvantages, the Council found a changeover from the Employment Principle to the Principle of Delayed Integration worthy of consideration.

This paper is structured as follows. Section 2 presents some numbers on cross-border migration in Europe. Not only is the current situation of interest, but also the extent of migration that is expected to result from Eastern Enlargement of the EU. Section 3 outlines the present regulations concerning free movement in the EU. Section 4 explains how migrants are taxed and covered by social security. A critical assessment of the Employment Principle is 
given in Sections 5 and 6, and possible alternatives are discussed in Section 7. The Principle of Delayed Integration is explained and appraised in Section 8.

\section{Migration in Europe and Eastern Enlargement}

In Germany and Austria there is much concern about excessive immigration as a result of Eastern Enlargement. For similar reasons, non-active citizens of the Union are denied an unrestricted right to free movement. There is a fear of social tourism. Such concerns about excessive migration could be allayed with the argument that they have no basis in reality: There is relatively little migration within Europe. This applies to both migration within countries $^{1}$ and cross-border migration. In 1993, there were approximately 17 million foreigners in the EU, corresponding to $4.6 \%$ of the total population. 12 million people (3.3\%) were nationals of third countries and only 4.9 million (1.3\%) were European citizens (Bauer and Zimmermann, 1999, p 3). There is considerable variation hidden behind such averages, however. The share of foreign nationals varies considerably across countries (OECD, 1999). It is below 2\% in Finland and Spain, whereas it reaches 19\% in Switzerland and 35\% in Luxembourg. With values in the order of $9 \%$ it is moderately high in Austria, Belgium and Germany. Sweden has roughly $6 \%$ foreign nationals which is the highest share among Scandinavian countries

Now it would be wrong to infer a low propensity to migrate from low shares of foreigners. A low level of migration could be a sign of a migration equilibrium. Still, the need for political intervention cannot be ruled out. A migration equilibrium need not be allocationally efficient. Rather, residence choices could be fiscally distorted, which would raise the question of appropriate political measures to be taken.

Low shares of foreigners in the EU could alternatively result from obvious or hidden barriers to free movement. It is the non-active citizens of the Union and the nationals of third countries, in particular, who are mobility constrained by present law. Once again it would be

\footnotetext{
${ }^{1}$ In 1987, 2.8\% of all Americans moved between federal states. This compares with only $1.1 \%$ of the Germans, $1.1 \%$ of the British and $0.6 \%$ of the Italians who moved between regions within their respective countries (Krueger, 2000, p. 123). A remarkable 1.9\% is reported for Sweden. This is high by European standards. In Sweden migration seems to be more responsive to economic conditions than elsewhere in Europe (Fredriksson, 1999).

${ }^{2}$ When comparing such numbers one should bear in mind that countries pursue different policies of naturalisation. The rule is in Europe that 1-3\% of the foreign population acquires nationality in each country
} 
an error to conclude that there is a low propensity to migrate just because measured migration is low. On the contrary, removing restrictions to free movement can trigger off large flows of migration. The countries affected have to be prepared for high and, in some cases, overshooting levels of migration for at least a transitional period. Migration needs time to adjust to a new equilibrium. It is in the nature of such disequilibrium adjustment processes that their prediction is highly unreliable. Eastern Enlargement appears to be no exception to this.

The fact that Eastern Enlargement cannot be compared to earlier rounds of enlargement of the EU only makes projections particularly difficult. At the time when Spain joined the Union as part of the Southern Enlargement, its real GDP per capita was at $70 \%$ of the EU average. Even Portugal reached 50\%. In contrast, in 1997 GDP at purchasing power parity per capita of countries such as Lithuania, Latvia, Rumania and Bulgaria was in the range of $20 \%$ of the EU average. The country with the highest income was Slovenia with $58 \%$. ${ }^{\text {Under }}$ these circumstances, estimates of transboundary migration after accession are problematic. This may explain the relatively large discrepancies in two studies that have recently been completed. One is by DIW (2000) and the other by Sinn et al. (2001). According to the calculations of DIW, immigration from the ten Central and Eastern European candidates of accession will hardly exceed one percent of the Union's residential population in the first 15 years after accession. ${ }^{1}$ However, it is expected that immigration will be highly concentrated towards Germany and Austria. This is explained by the close geographic proximity and the fact that both these countries have already been the preferred destinations in the past. In 1993, as much as two-thirds of the immigrants from the Central and Eastern European candidates of accession chose to live in Germany. If the Aussiedler 5 were included, this figure would rise to no less than $91 \%$. DIW predicts that the share of immigrants from the CEECs will make up $3.2 \%$ of the German residential population in 2020. This corresponds to $2.4 \%$ of the residential population in the countries of origin. Sinn et al. (2001) project roughly 80 percent more immigration to Germany, and this despite leaving Rumania and Bulgaria out of consideration. According to their estimates the immigration potential amounts to 3 million people.

every year. There are however countries, notably the Netherlands, Norway and Sweden, in which the fraction approaches 10\% (OECD, 1999; Wildasin, 2000, pp. 351).

${ }^{3}$ Figures taken from Boeri and Brückner (2000, Part A, Table 3.1; Part B, Box 2.1).

${ }^{4}$ Besides the mentioned countries, these are Poland, the Czech Republic, Slovakia, Hungary and Estonia.

${ }^{5}$ Aussiedler are East Europeans with German ancestors. 
A sound economic judgement as to whether such migration is desirable or not can only be made on the basis of the expected allocational and distributional effects. According to economic theory, migration is basically efficiency enhancing. In this very sense, migration must be regarded as desirable. For other reasons, some of which have already been mentioned, one can take a more critical view of migration. For example, as a reaction to the removal of mobility constraints, overshooting migration can arise. Furthermore migrational choices can be fiscally distorted. Finally, distributive effects can be seen as problematic. Losses of income have to be reckoned with for those parts of the labour force who become relatively more abundant due to immigration and whose remuneration comes under competitive pressure. Relative wage reductions are particularly problematic if they affect low-skilled labour. On the other hand, the available empirical evidence suggests that one should not expect large losses. Quite to the contrary, the effect that immigrant inflows have on the relative wage structure seems to be rather moderate. At least this is the conclusion to be drawn from a careful - albeit- American study by Card (2001). See also the survey by Bauer and Zimmermann (1999, Sect. 3.2). The latter estimate that immigration of $1 \%$ of the EU-population in one year may imply aggregate income losses for the EU-population of $0.7 \%$ in 1993. However such losses only appear in a worst-case scenario characterised by rigid wages and unskilled immigrant labour. If mainly skilled workers immigrate, one can actually expect income gains. EU GDP is then estimated to rise by $6.9 \%$ if the EU labour force increases by $1 \%$ in one year. In what follows the focus is not on the welfare implications of migration as such. Rather the focus is on the fiscal distortions of mobility.

\section{Free Movement in the $\mathrm{EU}$}

As mentioned before the right of free movement is not enjoyed by all citizens of the Union to the same extent. Only active persons, more precisely persons who are put on an equal footing with active persons such as family members and surviving dependants, are completely free to move and to reside within the territory of the Member States. Non-active persons, more precisely persons who are not put on an equal footing with active persons, are restricted in their freedom to move. Member States may well take a more liberal stance towards migration and the Nordic countries do in fact whenever own citizens are affected. However the rule for the Union is that Member States limit the right of residence and they are even authorised to do so. Thus immigrants must have sickness insurance and sufficient resources at their disposal in order to ensure that they avoid becoming burdens on the social assistance system of the 
country of immigration during their stay ${ }^{6}$ For recipients of social assistance, this provision means that they have de facto no freedom to move. It is precisely because they do not dispose of sufficient resources that they have to rely on social assistance. By moving abroad they, however, lose their claim to welfare support. Social assistance is not portable. According to German law, social assistance can be but need not be granted to German nationals residing

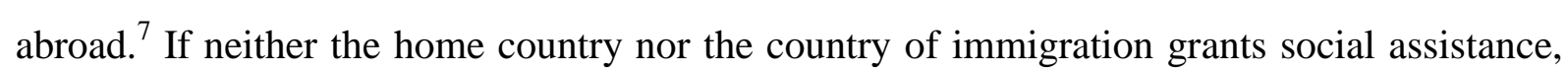
the freedom to move does not really exist for the needy.

It is certainly not in conformity with the spirit of Maastricht if the freedom to move takes on a different shape for different groups of people (Sasklin, 1997, p.205; Wissenschaftlicher Beirat, 2001). The Treaty of Maastricht introduced the status of Union Citizenship and conferred on beneficiaries not only the right to vote and to stand as a candidate at municipal and European elections. As mentioned before, citizens of the Union were also granted the right to move and reside freely within the territory of the Member States. Although this right is subject to contracted limitations and conditions in accordance with Community law, the contracting parties must, however, have had in mind that such limitations will and should not last for ever. The explicit reference to the freedom to move in Article 18 of the EEC Treaty only makes sense if one assumes that the right to free movement should also be granted to those persons who do not already enjoy this right by virtue of other provisions. Since the right to free movement is already guaranteed to active persons or persons on an equal footing by Articles 39 and 43 of the EEC Treaty, one has to infer that the contracting parties in Maastricht were decided to regard employment no longer as an absolute requirement for free movement.

\section{Avoiding International Collision in Taxation and Social Security}

Whenever citizens exercise their right to free movement, it becomes necessary to fix jurisdictional memberships and competencies. Citizens and jurisdictions need to be assigned to each other, and there are collision norms in international tax and social security law to regulate this. The various provisions are, however, anything but uniform both technically and in terms of content. For instance, jurisdictional membership is regulated by individual residence in international taxation whereas it is the competence of authorities which governs

\footnotetext{
${ }^{6}$ Directive 90/364/EEC of 28 June, 1990, OJ No. L180, p. 26; Directive 90/365/EEC of 28 June, 1990, OJ No. L180, p. 28; Directive 90/366/EEC of 28 June, 1990, OJ No. L180, p. 30; Directive 93/96/EEC of 29 October, 1993, OJ No. L317, p. 59.
} 
jurisdictional memberships in the international law of social security. In spite of the many differences in the details, it can nevertheless be argued that jurisdictional membership relies on the Employment Principle as far as the EU is concerned. This is revealed by a closer look at the various provisions.

As far as direct taxation is concerned, collision is avoided by the application of bilateral tax conventions. One has to rely on such conventions as the EEC Treaty provides no legal basis for co-ordinating national policies in the field of direct taxation. The bilateral tax conventions closely follow the OECD Model Tax Convention on Income and on Capital. Article 4 of this Model Convention rules that whenever the residence of a person is in need of clarification, in the first instance, he shall be deemed to be a resident of the State in which he has his permanent home available to him. Special provisions, however, apply when dealing with cross-border matters. For example, Article 15 of the OECD Model allocates the right to levy taxes on earned income to the country of employment if that employment exceeds an agreed period of time. It is then the responsibility of the residence country to avoid double taxation.

This general provision does not rule out special ones in specific bilateral tax conventions. Several countries have agreements with their neighbours according to which so-called frontier workers, regular commuters across the border, are subject to taxation in the country of residence. ${ }^{8}$ Aside from such atypical special provisions, it is the country of employment which has the right to levy taxes on earned income in the EU.

Employment-based taxation goes so far that workers in Germany who are resident abroad can apply to be taxed as if they were resident in Germany. In this way, they enjoy all the personal and family tax concessions that a resident can claim. It was only in 1996 that Germany enacted this provision thus reacting to the Schumacker ruling by the European Court of Justice in $1995 .{ }^{6}$ This development can be interpreted as a confirmation and a strengthening of the Employment Principle (Wissenschaftlicher Beirat, 2001. p. 52).

The Employment Principle also dominates social security law, at least as far as the scope of Regulation (EEC) No. 1408/71 on social security for migrant workers is concerned. Persons

\footnotetext{
${ }^{7}$ Section 119, paragraph 1 Bundessozialhilfegesetz (German Social Assistance Act).

${ }^{8}$ Bilateral double-taxation agreements which contain such special provisions are summarised by Frontier Workers in the European Union, European Parliament (ed.), Directorate General for Research, Working Paper W 16A, Social Affairs Series, May 1997, Annex 2.

${ }^{9}$ Ruling of 14 February, 1995; Case C-279/93.
} 
who pursue employment or who are self-employed in a Member State are subject to the social legislation of that state. The competent authority for social security is the authority at the place of employment. The Residence Principle only applies by way of substitution. It applies, for instance, for persons who are on an equal footing with active persons, without actually being employed themselves. Besides family members and surviving dependants, these are unemployed persons, retired persons and students.

The legal assignment of posted workers has recently drawn particular attention. Workers are posted if their employment abroad is expected not to exceed one year. As an exception to the rule, posted workers are not assigned to the country of employment. Rather, according to Article 14 of Regulation (EEC) No. 1408/71, they are subject to the legislation of the country from which they are posted.

In the years following German Reunification, the status of posted construction workers was the focus of much political attention. A high number of foreign workers in a period of high unemployment amongst German construction workers was seen in Germany as an abuse of the laws on posting. There was talk of "social dumping". ${ }^{10}$ The German government responded by passing the controversial "Arbeitnehmer-Entsendegesetz", the act regulating posted workers. ${ }^{-1}$ According to this law, the application of a German wage agreement extends, under certain conditions, to workers posted to Germany. Foreign companies and governments regarded such a provision as a violation of the EEC Treaty. This view did not win recognition, however. Rather, with the passing of Directive 96/71 2 Germany's position was approved at the European level. The Directive restates the principles of free labour mobility and free movement of services. At the same time, it grants Member States the right to set minimum compensation standards which are binding for firms even if these have their headquarters abroad and only carry out work in the Member State for the account of third parties. This development can equally be interpreted to confirm and strengthen the Employment Principle.

\footnotetext{
${ }^{10}$ Compare Bean et al. (1998, p. 50); Haverkate and Huster (1999, p. 113).

11 of 26 February 1996, last amended with Article 10 of the Act on 19 December, 1998.

12 of 16 December, 1996. See OJ EC No. L18, p. 1, of 21 January, 1997.
} 


\section{Critical Assessment of the Employment Principle}

The employment-based regulation of jurisdictional memberships and competencies has advantages and disadvantages. It is chiefly the disadvantages which will be examined here. The most obvious drawback is a result of the fact that the Employment Principle is not applicable to non-active persons. Either special provisions become necessary if non-active persons may wish to migrate or some discrimination of such persons must be accepted. It has already been pointed out that an unequal treatment of Union Citizens hardly conforms to the spirit of the Treaty of Maastricht. Special provisions are just as problematic, however, because the separation of employment and non-employment is difficult to enforce in practice. According to a ruling of the European Court of Justice, as few as 10 to 12 hours of work per week may suffice for a person to qualify as working from a legal point of view. ${ }^{3}$ Once being qualified as working, such a person is eligible to all the social benefits granted in the country of employment, supplementary social assistance, housing and child benefit, in particular. Economic reasoning suggests that the claim to such benefits impacts residential and occupational decisions even if it is only a conditional one. In any case, special provisions for non-active persons are difficult to enforce if the only objective is to deny these persons workrelated social benefits.

Even if one could ignore migration of non-active persons, the Employment Principle would still give reason for criticism on allocational grounds. In order to understand this kind of criticism one has to consider the joint interest of the countries of emigration and immigration. Labour is a factor of production which, in the case of perfect mobility, is only then globally efficiently allocated if its marginal product is equated across countries. The marginal product is reflected by the firms' cost of labour. When making locational decisions, workers do not compare costs of labour however. Instead, they compare wages net of taxes and subsidies. A migration equilibrium is, therefore, characterised by equalised net wages. Such a behaviour is only able to sustain production efficiency if equated net wages translate into equated costs of labour. Obviously a precondition for this to result is that the tax-subsidy wedge is of the same magnitude in the different jurisdictions. Only policy harmonisation can ensure this. Policy harmonisation, as has been explained, is no viable option for the EU, however. Hence the Employment Principle induces an internationally inefficient allocation of labour.

\footnotetext{
${ }^{13}$ See Becker, 1999, p. 525 for references to the ruling of the Court of Justice.
} 
The Employment Principle is also criticised for impeding non-paretian distributive policy pursued at the national level . In order to provide a better explanation of this objection, it is advisable to make some simplifying assumptions. Suppose that the labour force divides into perfectly mobile and perfectly immobile workers. Both groups are complementary in production, so that the productivity of one factor increases with the availability of the other. This division into mobile and immobile is exogenous and not, for instance, the result of human capital investment. In such circumstances immobile labour cannot wish mobile labour to be taxed in the country of employment. Perfectly mobile workers must earn an internationally competitive wage. Hence their net remuneration cannot fall short of what is paid elsewhere in the world. By emigrating, they are able to avoid any wage tax levied at source. Any tax on mobile labour which is not internationally harmonised is, therefore, shifted backward. This is harmful for the immobile factor. Not only is it left with the full tax burden, but as a result of factor complementarity, its productivity is less than it would be without taxation. ${ }^{14}$ This effect may be particularly frustrating politically if mobile labour is more productive than immobile labour, i.e. if there is a positive correlation between mobility and wage income. In this case, the distributive goal cannot be achieved effectively. It would be in the best interest of the lowincome immobile labour to let high-income mobile labour get away without its wage being taxed.

A positive correlation between mobility and earned income not only seems highly plausible. A willingness to move is surely encouraged by cosmopolitanism, a knowledge of foreign languages, etc and thus by innate and acquired intellectual abilities which tend to have a positive effect on labour productivity. A positive correlation is also supported by empirical evidence. The empirical studies tend to focus on the connection between mobility and education. 15 A significant positive correlation between education and the probability of migration is shown by all studies of internal migration. The results are more ambiguous for international migration. This often has to be explained, however, by political constraints on free mobility.

\footnotetext{
${ }^{14}$ Compare Sinn (1994a, p. 172, 1994b, p. 97) for a detailed analysis of the tax shifting mechanism. The mechanism is well-known from the theory of international capital taxation. To see the parallels, simply replace mobile labour with mobile capital. Taxing labour at the place of its employment then corresponds to taxing capital at source.

${ }^{15}$ A recent survey of the literature is provided by Bauer and Zimmermann (1999, Section 2.2.2).
} 


\section{Qualifying the Criticism of the Employment Principle}

The negative allocation effects of the Employment Principle asserted above should also be put into perspective. It is frequently doubted that the propensity to move is sufficiently pronounced to have the distortive effects indicated. Such objections need to be tackled empirically and theoretically.

Feld (2000a, Section 2.2.2) ${ }^{16}$ has recently provided a comprehensive survey of the empirical literature on fiscal competition in Tiebout's tradition. According to Feld, a distinction between the different causes of fiscally induced mobility must be made when evaluating this literature. The recipients of social assistance obviously strongly respond to the transfer level. At least this has been shown for the USA for the period since 1969. In that year, the Supreme Court ruled that the Residence Requirements for the recipients of welfare payments were in breach of the American Constitution. According to these requirements, transfer benefits were conditioned on years of residence and on the labour market status of the potential claimants. Since 1969, all US citizens or lawfully resident aliens may claim welfare payments in the State where they reside. ${ }^{1.7}$ As to the effect that taxes have on residence choices, the empirical evidence is more mixed (Feld, 2000a and 2000b). In the USA, this could be due to the fact that the States and local authorities are financed through income taxes only to a minor extent. In Switzerland, the empirical results tend to be reversed. Social transfers there play a comparatively small role in the locational choice of residence. In comparison, local taxes seem to have a stronger effect on residence choices. This is especially the case for high-income earners, who, incidentally, also react positively to local public expenditures. Low-income earners are not as strongly influenced by taxes in their locational choice of residence. On balance, taxes are more important than social transfers for fiscally induced mobility in Switzerland. 18

A viable model of locational choices must account for the fact that individuals do not only compare incomes net of taxes and transfers. There are moving costs which have to be offset against potential income gains. Consumer price differences concerning non-tradables have to considered too. Finally, as emphasised by Tiebout (1956), persons willing to migrate will

\footnotetext{
${ }^{16}$ Also compare the summarising article by Feld (2000b)

${ }^{17}$ According to Borjas (1999), welfare assistance also influences immigrants' locational choice of residence in the USA. Even though the influence is of relatively weak significance, it does exist. In 1990, for example, 45\% of the new immigrants who were recipients of welfare assistance lived in California, a state which stands out due to its relatively high welfare rate. In contrast, only $29 \%$ of the new immigrants who did not receive welfare assistance lived there.

${ }^{18}$ See also Feld (2000c) and Feld and Kirchgässner (2001).
} 
relate the local tax bill to the local supply of public goods. In short, migration decisions are not based on pure wage, but on utility arbitrage. This suggests at least two conclusions. First, interregional wage differentials need not be an indication of mobility imperfection. Second, the fear that employment-based taxation renders distributive policy in favour of immobile individuals impossible may be exaggerated. If distributive policy is sustained by preferences, even with perfect mobility there need not be emigration of those who are taxed. Paretian redistribution should, rather, be regarded as a public good which is efficiently provided if only taxpayers' altruism is restricted to the region of residence and if jurisdictional competition among regions is perfect. 19

It is non-paretian redistribution that, above all, suffers from competitive pressure. Taxes that merely cover the cost of rivalry in consumption must be levied according to the Benefit Principle if allocational efficiency is to be achieved. This means that such taxes should be levied employment-based if the cost of providing such goods is employment related. The taxes are set first-best efficient if, just as the marginal-cost pricing rule would suggest, they cover the cost which the jurisdiction incurs by the marginal job. This means that the taxes would in principle have to be imposed as a poll tax if the cost incurred by the jurisdiction is related to the creation of the job and not to earned income. When taxes are based on income or expenditure, as is commonly the case, allocational efficiency is at risk. In particular, labour supply decisions will be distorted if taxes are wage related although costs incurred by the jurisdiction are not. Migration decisions still remain undistorted if only the location-specific tax equals the cost that is caused by the free provision of local public goods and services to the marginal individual. A detailed analysis of the various distortions of possible forms of taxation goes beyond the scope of this paper. It should be noted, however, that employmentbased taxes are efficiency enhancing to the extent that they can be rationalised by the Benefit Principle.

Now one may rightly doubt that the high level of employment-based taxes and social security contributions in Europe can be justified by the Benefit Principle. A recent attempt to support such scepticism empirically is made by Sinn et al. (2001). ${ }^{2}$ In their study, the direct fiscal effects of immigration per immigrant and year are calculated for West Germany for 1997. More precisely, the present values of tax revenues and the various social insurance

\footnotetext{
${ }^{19}$ The theory of fiscal competition in Tiebout's tradition is excellently presented by Wellisch (2000). Also compare the overview by Oates (2001).

${ }^{20}$ Also compare Sinn and Werding (2001) from which the following is taken.
} 
contributions (health, pension, nursing care and unemployment) are summed up and balanced against the present values of social insurance benefits, tax-financed transfers as well as other state transfers. The figures are then broken down according to the length of stay of the immigrants. The calculated net fiscal balance is more negative, the shorter the length of stay. For longer lengths of stay, by contrast, it becomes positive. More precisely, the net balance amounts to Euro $-2,300$ for a length of stay under 10 years. For a stay of over 25 years, by contrast, it is positive. See the following table. Similar results are produced by Gustafsson and Oesterberg (2001) for Sweden.

\section{Direct Fiscal Impact of Immigration}

- West Germany 1997 -

\begin{tabular}{|l|l|l|l|l|}
\hline & \multicolumn{2}{l|}{ Length of Stay in Years } & \multirow{2}{*}{ Total } \\
\cline { 2 - 5 } & $0-10$ & $10-25$ & $25+$ & 8,776 \\
\hline $\begin{array}{l}\text { Revenues p.a. } \\
\text { of which tax }\end{array}$ & 6,578 & 7,370 & 11,081 & 3,874 \\
\hline $\begin{array}{l}\text { Expenditures p.a. } \\
\text { of which tax-financed } \\
\text { transfers } u . \text { benefits }\end{array}$ & 3,090 & 3,091 & 4,953 & 9,502 \\
\hline \begin{tabular}{l} 
Net Balance in $€$ \\
\hline
\end{tabular} & $-2,368$ & 8,702 & 10,226 & 6,308 \\
\hline
\end{tabular}

Source: Sinn and Werding (2001, p. 45).

Sinn and Werding (2001, p. 44) explain the change from a negative to a positive balance as follows. The majority of immigrants initially work in low-skilled jobs. They earn belowaverage incomes and pay correspondingly low taxes and social security contributions. At the same time, they benefit from tax-funded transfers and payments to a large extent. For a number of years they are, therefore, the beneficiaries of the redistribution which is characteristic of the German - and every other West European - tax and transfer system. With increasing length of stay the immigrants assimilate economically and eventually reach the average income of natives.

Since there is, empirically, a positive correlation between mobility and earned income, it must be assumed that immigrants tend to be net losers of the tax-transfer system in their home 
country. The net loss in the home country contrasts with a net gain in Germany, as the country of immigration, at least for the first few years. This results in an artificial incentive to migrate. The incentive is artificial since it is fiscally induced and not underpinned by productivity differentials. It is one that need not become effective, for instance, when individual mobility costs are large and productivity differentials small. However it will bias the decision to migrate on the margin. Now a net gain of approximately Euro 2,300 per capita and year may be considered a small amount. That would be wrong, however. After all, Euro 2,300 per capita and year amounts to $9 \%$ of the gross wage (including the employers share of social security contributions) of a single person or roughly $30 \%$ of the gross wage of an average 3.3-

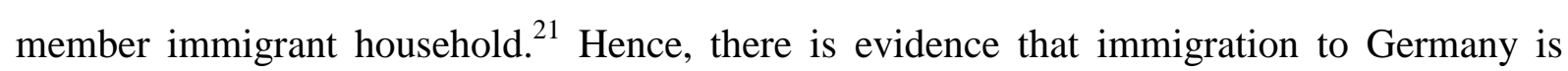
fiscally distorted and that this distortion is substantially attributable to taxation and social security, which are employment-based.

\section{Alternatives to the Employment Principle}

Theoretically, there are several possibilities to eliminate the distorting effect of employmentbased taxation on migration while sticking to the freedom of movement. Certain fairly obvious possibilities do not constitute viable political options, however. One of these is the adoption of the Nationality Principle as a substitute for the Employment Principle. Despite certain economic advantages, which will be described in connection with the Origin Principle, the Nationality Principle cannot be the basis for co-ordinating national policies in the EU. Treating Union Citizens differently according to their nationality would be interpreted as a form of discrimination which is expressly forbidden in Article 12 of the EU Treaty. Regulating migration by means of taxation is not a viable solution for the EU either. Taxing emigration and/or immigration would be interpreted as a violation of the right to free movement and would therefore have little chance of realisation. 22

Another proposal with doubtful prospects of political success provides for a transition from the Employment Principle to the Origin Principle. This option was brought up by Sinn (1994) who chose to speak of the Home Country Principle and who pleaded for its adoption with a

\footnotetext{
${ }^{21}$ These numbers are taken from the German translation of Sinn and Werding (2001). One need not stress that they are to some extent debatable. In a different study Bonin (2001) finds that the fiscal balance of immigrants to Germany is positive on average. Any such result is heavily dependent on the kind of social and economic characteristics assumed to hold for immigrants. E.g. it seems to make much of a difference whether immigrants are refugees or not (Hansen and Lofstrom, 2001; Gustafsson and Oesterberg, 2001).

${ }^{22}$ Whether it is economically compelling to qualify any tax on migration as an obstacle to free movement is a different thing. To the extent that the tax on migration only serves the neutralisation of fiscal distortions, one could well maintain the opposite.
} 
particular conception of the welfare state. According to Sinn, it is the primary function of the welfare state to provide insurance against income risks and uncertain life careers. What appears ex post to be redistribution is insurance from an ex ante point of view. Whenever individuals are allowed to switch insurance freely ex post, there is the risk of adverse selection. This weakens the ex-ante insurance function which the welfare state is expected to provide. According to Sinn, individuals should therefore only be free to choose between competing redistributive systems ex ante when young and ignorant about career perspectives. The redistributive system they choose then defines the country of origin, or the home country, respectively. Switching the country of origin ex post should not be allowed. Sinn rejects the Employment Principle not only because it distorts migration decisions, but, above all, because it undermines the insurance function of the welfare state.

The Origin Principle shows certain similarities to the Nationality Principle without being equivalent. On the one hand, it is more liberal than the latter as it allows a free first choice among redistributive systems. On the other hand, it is more restrictive as it rules out any later switch in life. "Origin" may have fewer negative political connotations than "nationality" and, in this respect, a change in Europe from the Employment Principle to the Origin Principle may have somewhat better chances than a change to the Nationality Principle. With regard to economic incentives, by contrast, the difference between the two principles is not that large. Therefore, it should suffice if the discussion of specific features is restricted to the Origin Principle. On the positive side, migration decisions are not distorted by taxes and transfer payments. Individuals cannot escape their origin, once fixed, by migrating. Production efficiency is maintained internationally since net wage arbitrage implies equalisation of gross wages and marginal products of labour. Distributive policies by individual countries are not thwarted by mobile taxpayers' threat to emigrate. The country of origin also shares the gain in income that the emigrants make. Hence, there is income redistributed from countries of immigration to countries of emigration, which helps to mitigate regional shocks. Finally, and positively, it should be noted that the Origin Principle, unlike the Employment Principle, is applicable to non-active persons. These individuals can be granted the right to free movement without the threat of social tourism arising.

On the other hand, the Origin Principle does have shortcomings which cannot be ignored (Richter, 2001a). First, an origin-based assignment of emigrants to their home country necessitates an extensive delegation of tax levying and monitoring functions. Such a 
delegation is problematic because the incentive to use foreign public funds economically may not be particularly great. At least the delegation of administrative functions has to be designed carefully in order to cope with the resulting principal-agent problem. Second, the origin-based assignment conflicts with a policy targeted at the integration of immigrants. Note that the Origin Principle requires the latter to remain assigned to their country of origin even if they decide to leave it for ever. For this reason, the country of origin is able to pursue a policy of non-paretian redistribution, but any policy of paretian redistribution will not be sufficiently internalised. ${ }^{23}$ This may cause a problem if distributive policy needs to be supported by the population. A sense of solidarity with the beneficiaries of redistribution is a prerequisite for this. Common origins may well favour such a sense of solidarity. However, their relevance tends to dwindle in course of time. The disadvantage of the Origin Principle is that it is oriented purely towards the past and that it is blind to dynamic changes in the composition of a population. Distributive policy is more likely to be met with approval if it is tied to the present and not to the past. This speaks for the principles of employment or residence and against the Origin Principle.

Such considerations concerning the effectiveness of distributive policy are based on a benevolent planner approach. The argument against the Origin Principle is strengthened if one adopts a Leviathan-state perspective. For it is clear that the Origin Principle provides governments with the leeway to abuse their fiscal power. Taxpayers cannot threaten to emigrate. As a result, the incentive for governments to pursue a policy in the interest of their citizens is weak. The Origin Principle is not favourable to competition among jurisdictions. The Employment Principle has more of a disciplinary effect on Leviathan governments.

The same applies to the Residence Principle. This principle is probably the most liberal rule of assigning individuals to jurisdictions. It respects private decisions to migrate without imposing activity requirements. It is, however, rarely adopted when international migration is concerned. A prominent exception is given by the Nordic countries. In all these countries the right to social security is based on residence and all lawful residents, including recipients of social assistance and third-country citizens, enjoy free movement. Sufficient resources are not a condition for the entry. Expulsion is not possible for reason of insufficient resources after three years of residence (Sakslin, 1997).

\footnotetext{
${ }^{23}$ Compare Pauly (1973).
} 
Now it is doubtful whether the Nordic practice can serve as an example for the EU. Two objections can be raised. First, the negative allocational effects of the Employment Principle would hardly be reduced. Since migrant workers tend to change their place of residence together with the place of work, the switch from the Employment Principle to the Residence Principle would have little effect. At most, frontier workers, persons who are employed in one Member State and live in another, would be affected by such a reform. ${ }^{24}$ Second, it is fairly obvious that the Residence Principle provides an open invitation for the recipients of social assistance to shop around and to choose their residence with an eye to the local level of welfare support. The Member States would not stand idly by. Without restrictions on immigration the much feared "race to the bottom" in social standards would be a realistic menace.

The Nordic countries can live with the Residence Principle because they are relatively homogeneous economically. Both GDP per capita and social protection expenditures per capita are at a similar level (Bertola et al., 2001, p.31). For this reason, there is no systematic social tourism, and possible distortions to migration are negligible. One can even do without fiscal equalisation and without balancing financial burdens between the countries. The costs that immigrants inflict on the receiving country are not charged to the country of origin (Sasklin, 1997, p.199). The situation is quite different in the EU. In terms of income per capita and social protection expenditure as percentage of GDP, there are vast differences between the Nordic and continental core countries, on the one hand, and the Southern European countries, on the other hand. See the following table. Hence, one may doubt that the Residence Principle is a viable option for the EU, at least in the foreseeable future. It may be different in some distant future. Scandinavia is an example sustaining such hopes. At the time when the Nordic countries introduced free mobility differences in GDP between Sweden and Finland were roughly of the same order as those displayed by the following table. Although there was a large influx of immigrants from Finland to Sweden at that time free mobility and the Residence Principle were never repealed. 25

\footnotetext{
${ }^{24}$ The number of frontier workers in Europe for the period 1990 to 1995 has been estimated at 380,000 on average. See Frontier Workers in the European Union, Fn. 7.

${ }^{25}$ This has been noted by John Hassler in a private communication to the author.
} 
Income and Social Protection Expenditure in the EU

\begin{tabular}{|l|l|l|}
\hline & $\begin{array}{l}\text { GDP per capita in 1994 at } \\
\text { PPS (EU12=100) }\end{array}$ & $\begin{array}{l}\text { Social protection expenditure } \\
\text { in 1994 as \% of GDP }\end{array}$ \\
\hline Greece & 61.8 & 16.0 \\
\hline Portugal & 63.3 & 19.5 \\
\hline Finland & 89.9 & 34.8 \\
\hline Denmark & 110.6 & 33,7 \\
\hline
\end{tabular}

Source: Bean et al. (1998, p. 16).

\section{The Principle of Delayed Integration}

In a certain sense the Origin Principle, on the one hand, and the principles of employment or residence, on the other hand, represent extreme solutions to the problem of assigning migrants to jurisdictions. The Origin Principle does not permit any switching of jurisdictional membership while the principles of employment and residence leave the decision to switch completely to the discretion of the migrant. Since these solutions are extreme, it comes as no surprise that they are open to criticism. Besides certain merits, they also have serious shortcomings. Even more: what appears to be an advantage of one solution can be regarded a disadvantage of the other, and vice versa. For example, there are no distortions to migration with the Origin Principle if local redistribution is non-paretian, whereas the principles of employment and residence induce such distortions. The reverse also holds: The latter principles favour an internalisation of the cost of providing local public goods at the place of work and residence, respectively, while the Origin Principle does not permit such an internalisation.

Whenever extreme solutions are not completely convincing, it seems reasonable to seek for compromises. The Principle of Delayed Integration represents one such compromise. It means that moving from one country to another will result in a delay in reassignment for fiscal purposes. The longer the chosen duration of the delay, the closer this principle comes to the Origin Principle. The shorter the duration is, the more similar to the Residence Principle it becomes. This duration, or period of transition, is a parameter which can be used as a policy instrument. 
When fixing the period of transition, various aspects need to be considered. For instance the choice is nothing that can be left to the discretion of individual jurisdictions. Only if all jurisdictions agree to the same span of delay will collision in international tax and social security be prevented. Hence, periods of transition need to be internationally harmonised. ${ }^{26} \mathrm{~A}$ period of one to five years is discussed in the literature. ${ }^{\square}$ On the other hand, the same period need not be chosen for all areas of international tax and social security law. It can, and should, be kept short, and if necessary not used at all, wherever taxes are non-distortive, which is the case if they are set in accordance with the Benefit Principle. The reverse also applies: The more distortive taxes and subsidies are, the longer the period of transition should be. Accordingly long periods are justified for social assistance and progressive income taxation. What makes the concrete assignment of transition periods to systems of taxation or social security however so difficult is the fact that these systems serve different objectives from country to country 28 . For example, public pension systems of Germany, Austria, and France are organised as public insurance. Benefits are largely proportional to contributions and earned wages. This is commonly considered to be a characteristic feature of social security in the Bismarckian tradition. As the systems are financed on a pay-as-you-go basis the primary distributive effect is intergenerational. This contrasts with the public pension schemes of other countries, notably the United Kingdom, Ireland and the Netherlands. Standing more in the tradition of Beveridge these schemes largely provide subsistence-level flat-rate benefits and they make extensive use of means-testing. Hence they are much more redistributive than Bismarckian schemes and without structural harmonisation it would become difficult to argue for some specific period of transition.

There is currently an international trend towards aligning social security with the benefit principle. Some pertinent keywords are earnings-related benefit schemes, individual accounts and funding. The argument in favour of delaying integration obviously gets the weaker the more systems of taxation and social security accord to the benefit principle. However this does not mean that the argument becomes obsolete. As long as countries pursue their own distributive policies there is need to keep fiscal distortions of migration small. It is this

\footnotetext{
${ }^{26}$ The need for harmonising periods of transition is not specific to the Principle of Delayed Integration. In a certain sense such harmonisation is already part of policy co-ordination in the EU. It is only more implicit and, above all, discriminatory. While the period of transition is zero as far as active persons are concerned, it is infinity for non-active persons.

${ }^{27}$ Sasklin (1997, p. 213), Wissenschaftlicher Beirat (2001).

${ }^{28}$ See Disney and Johnson (2001) for a recent survey of pension systems in selected OECD countries.
} 
objective which justifies to study alternatives to the Principle of Employment and to discuss the merits of delaying integration.

It must be stressed that no curtailment of the right to free movement is intended with Delayed Integration. The main thing is to make migration decisions less dependent on the implications they have for taxation and social security. This is not least the prerequisite to granting nonactive Union Citizens full rights to free movement without triggering off unsustainable forms of social tourism. During the period of transition, it would remain the full responsibility of the home country to provide social assistance. This not only means that home countries are burdened by welfare payments for a couple of years, as is the practice in Germany and Switzerland for internal migration. The Principle of Delayed Integration goes beyond the balancing of financial burdens by setting individual incentives. In particular, the idea is to grant migrants welfare payments which are fixed in their home country and for which the home country takes the political responsibility. Obviously, such rates may well deviate from those granted by the country of immigration.

Switching to Delayed Integration raises a number of questions which have been discussed in detail in the report of the Council of Economic Advisors to the German Ministry of Finance (Wissenschaftlicher Beirat, 2001). These can only be outlined here. It is immediately clear that delaying the jurisdictional assignment of migrants to the country of immigration necessitates the delegation of monitoring functions during the period of transition. Some thought would have to be given to the form that this should take. For reasons of practicability, migrants should be required to pay taxes and contributions to social security in the country of immigration according to the legal provisions which apply there. Taxes and contributions should then be transferred to the competent authority in the country of origin. It would be the responsibility of the home country to make a final tax assessment according to its own laws. Only after the period of transition has elapsed does the responsibility for assessing the immigrants for fiscal purposes change over to the country of immigration. Similar rules should apply to social insurance benefits. 30

\footnotetext{
${ }^{29}$ Wildasin (1999) compares public pension programs in EU Member States and finds that workers can often raise or lower their lifetime net wealth by 5 to 15 percent or even more just by moving between certain countries. Such numbers give some indication of the enormous differences between the various public pension systems.

${ }^{30}$ Switching social security systems should sensibly only be possible before the event insured has occurred. For instance, if a pensioner who has paid all his contributions into a scheme of his home county emigrates, the home country should have to pay old-age benefits, even if the pensioner emigrates after finishing his working life.
} 


\section{Conclusions}

Europe has made great progress in its efforts to overcome the political and economic separation of its Member States. The level of integration achieved cannot be estimated highly enough. The willingness to deepen integration finds particular expression in the introduction of Union citizenship and the prohibition of discrimination on the basis of nationality in the European Treaty. There is, however, a certain degree of strain between integration and subsidiarity. Integration is enhanced by the harmonisation of national policies whereas subsidiarity requires political autonomy of the Member States and/or regions. It is necessary to establish some sort of balance in this strained relationship. In order to do so, there is a need for a regulatory framework which allows for free movement at the individual level and which, at the same time, allows the pursuit of independent political objectives at an jurisdictional level. Rules of assigning individuals to jurisdictions are of fundamental importance in this regulatory framework. The necessity to differentiate between persons who belong to a jurisdiction and persons who do not also arises in an integrated Europe. Otherwise the claims to regional autonomy cannot be settled. Abandoning the notion of nationality as a rule of jurisdictional assignment without some form of replacement will not do. An important function of the notion of nationality has always been the regulation of the membership of individuals to home communities. Union Citizenship just does not do this. What is needed is a rule according to which Union Citizens are assigned to Member States for the purpose of taxation and social security. This rule must be integration-friendly and anchored in Community law. The Principle of (the Country of) Employment only partially serves this purpose because it does not cover all Union Citizens. Furthermore, it tends to distort migration decisions. After weighing up the various advantages and disadvantages, the Principle of Delayed Integration seems to be an alternative rule worth considering. It shares two attractive features. First it is a rule which would allow one to extend the policy of free movement to all citizens without discriminating between active and non-active ones. Second by fixing the period of delay it would allow policy makers to trade off competing objectives. The longer the delay is chosen the less will locational choices be fiscally distorted. The shorter it is the fiercer will fiscal competition be among Member States. Europe would have to strike a balance between such objectives. 


\section{References}

Bauer, T.K. and K.F. Zimmermann (1999), Assessment of Possible Migration Pressure and its Labour Market Impact Following EU Enlargement to Central and Eastern Europe, IZA Research Report No. 3, Bonn.

Bean, C., S. Bentolila, G. Bertola and J. Dolado (1998), Social Europe: One For All? (CEPR, London).

Becker, U. (1999), Freizügigkeit in der EU - auf dem Weg vom Begleitrecht zur Bürgerfreiheit, Europa-Recht, 522-533.

Bertola, G. et al. (2001), EU Welfare Systems and Labor Markets: Diverse in the Past, Integrated in the Future?, in: G. Bertola, T. Boeri and G. Nicoletti (eds.), Welfare and Employment in a United Europe (MIT Press, Cambridge), 23-122.

Boeri, T. and H. Brücker (2000), The Impact of Eastern Enlargement on Employment and Labour Markets in the EU Member States, (European Integration Consortium: DIW, CEPR, FIEF, IAS, IGIER, Berlin and Milano).

Bonin, H. (2001), Fiskalische Effekte der Zuwanderung nach Deutschland: Eine Generationenbilanz, IZA Discussion Paper No. 305, Bonn.

Borjas, G.J. (1999), Immigration and Welfare Magnets, Journal of Labor Economics 17, 607637.

Burda, M.C. (2000), Mehr Arbeitslose - Der Preis der Osterweiterung? Zur Auswirkung der EU-Erweiterung auf die europäischen Arbeitsmärkte im Osten und Westen, in: L. Hoffmann (ed.), Erweiterung der EU (Duncker \& Humblott, Berlin), 79-102.

Card, D. (2001), Immigrant Inflows, Native Outflows, and the Local Labor Market Impacts of Higher Immigration, Journal of Labor Economics, 22-64.

Disney, R. and P. Johnson (2001), Pension Systems and Retirement Incomes across OECD Countries (Edward Elgar, Cheltenham).

DIW (2000), EU-Osterweiterung: Keine Massive Zuwanderung zu erwarten, Wochenbericht 21, 315-326.

Feld, L.P. (2000a), Steuerwettbewerb und seine Auswirkungen auf Allokation und Distribution, (Mohr Siebeck, Tübingen).

Feld, L.P., (2000b), Fiskalischer Wettbewerb und Einkommensverteilung, Perspektiven der Wirtschaftspolitik 1, 181-198.

Feld, L.P. (2000c), Tax Competition and Income Redistribution: An Empirical Analysis for Switzerland, Public Choice, forthcoming.

Feld, L.P. und G. Kirchgässner, (2001), Income Tax Competition at the State and Local Level in Switzerland, Regional Science and Urban Economics 31, 181-213.

Fredriksson, P., (1999), The Dynamics of Regional Labor Markets and Active Market Policy: Swedish Evidence, Oxford Economic Papers 51, 623-648.

Gustafsson, B. and T. Oesterberg (2001), Immigrants and the Public Sector Budget Accounting Exercises for Sweden, Journal of Population Economics 14, 698-708.

Hansen, J. and M. Lofstrom (2001), The Dynamics of Immigrant Welfare and Labor Market Behavior, IZA Discussion Paper No. 360, Bonn.

Haverkate, G. and S. Huster (1999), Europäisches Sozialrecht, (Nomos Verlag, BadenBaden). 
Krueger, A.B. (2000), From Bismarck to Maastricht: The March to European Union and the Labor Compact, Labour Economics 7, 117-134.

Oates, W.E. (2001), Fiscal and Regulatory Competition: Theory and Evidence, forthcoming in: Perspektiven der Wirtschaftspolitik.

OECD (1999), Trends in International Migration: Continuous Reporting System on Migration, Annual Report, Paris.

Pauly, M.V., 1973, Income Redistribution as a Local Public Good, Journal of Public Economics 2, 35-58.

Richter, W.F. (2001a), Institutioneller Wettbewerb und die Regelung der Zuständigkeit von Institutionen für Personen, in: Wirtschaftspolitische Herausforderungen an der Jahrhundertwende, W. Franz et al. (eds.), (Mohr Siebeck, Tübingen), 503-517.

Richter, W.F. (2001b), Delayed Integation of Mobile Labor: A Principle for Coordinating Taxation, Social Security, and Social Assistance, CESifo Working Paper No. 624.

Sakslin, M. (1997), Can the Principles of the Nordic Conventions on Social Protection Contribute to the Modernisation and Simplification of Regulation (EEC) No. 1408/71?, in: 25 Years of Regulation (EEC) No. 1408/71 on Social Security for Migrant Workers, Swedish National Social Insurance Board, eds., Stockholm.

Sinn, H.-W. (1994), How Much Europe? Subsidiarity, Centralization and Fiscal Competition, Scottish Journal of Political Economy 41, 85-107.

Sinn, H.-W., et al. (2001), EU-Erweiterung und Arbeitskräftemigration: Wege zu einer schrittweisen Annäherung der Arbeitsmärkte, ifo Beiträge zur Wirtschaftsforschung 2, München.

Sinn, H.-W., and M. Werding (2001), Immigation Following EU Eastern Enlargement, CESifo Forum 2, Summer, 40-47; English translation of: Zuwanderung nach der EUOsterweiterung: Wo liegen die Probleme?, ifo Schnelldienst 8/2001, 18-27.

Tiebout, C.M. (1956), A Pure Theory of Local Expenditures, Journal of Political Economy 64, 416-424.

Weichenrieder, A. (2000), A Simple Rule for Taxing the Mobile Rich, Disc. Paper, University of Munich.

Wellisch, D. (2000), Theory of Public Finance in a Federal State, (Cambridge University Press, Cambridge).

Wildasin, D.E. (1999), Public Pensions in the EU: Migration Incentives and Impacts, in: Environmental and Public Economics: Essays in Honor of Wallace E. Oates, A. Panagariya, P.R. Portney and R.M. Schwab (eds.), (Edward Elgar, Cheltenham).

Wildasin, D.E. (2000), Factor Mobility and Fiscal Policy in the EU: Policy Issues and Analytical Approaches, Economic Policy 31, 337-378.

Wissenschaftlicher Beirat beim Bundesministerium der Finanzen (2001), Freizügigkeit und soziale Sicherung in Europa, Schriftenreihe des BMF, Heft 69, (Stollfuß Verlag, Bonn). 


\section{IZA Discussion Papers}

$\begin{array}{ll}\text { No. } & \text { Author(s) } \\ 473 & \text { J. C. van Ours } \\ 474 & \begin{array}{l}\text { J. T. Addison } \\ \text { L. Bellmann } \\ \text { A. Kölling }\end{array} \\ 475 & \begin{array}{l}\text { Z. Hercowitz } \\ \text { E. Yashiv }\end{array} \\ 476 & \begin{array}{l}\text { W. A. Cornelius } \\ \text { T. Tsuda }\end{array}\end{array}$

$477 \quad$ M. A. Clark

D. A. Jaeger
H. Gersbach

A. Schniewind

J. T. Addison

C. R. Belfield

G. Saint-Paul

E. Schlicht

P. Kuhn

C. Weinberger

H. Rapoport

A. Weiss

J. H. Bishop

L. Woessmann

L. Woessmann M. R. West

A. L. Booth

M. L. Bryan

R. L. Lumsdaine

E. S. Prasad
A. Ciccone
G. Peri

D. Del Boca

S. Pasqua

W. F. Richter
Title

Area

Date

A pint a day raises a man's pay, but smoking

5

$04 / 02$ blows that gain away

Unions, Works Councils and Plant Closings in

3

$04 / 02$

Germany

$$
\begin{aligned}
& \text { A Macroeconomic Experiment in Mass } \\
& \text { Immigration }
\end{aligned}
$$

Labor Market Incorporation of Immigrants in Japan and the United States: A Comparative Analysis

Natives, the Foreign-Born and High School the GED

Uneven Technical Progress and Unemployment

Unions and Employment Growth: The One Constant?

04/02

The Complexity of Economic Policy:

I. Restricted Local Optima in Tax Policy Design

04/02

Hiring Standards and Market Clearing

$04 / 02$

Leadership Skills and Wages

04/02

In-Group Cooperation in a Hostile Environment:

$04 / 02$ An Economic Perspective on Some Aspects of Jewish Life in (Pre-Modern) Diaspora

Institutional Effects in a Simple Model of Educational Production

04/02

Class-Size Effects in School Systems Around the World: Evidence from Between-Grade Variation in TIMSS

Who pays for General Training? New Evidence for British Men and Women

Identifying the Common Component of International Economic Fluctuations:

A New Approach

Identifying Human Capital Externalities:

Theory with an Application to US Cities

Employment Patterns of Husbands and Wives and Family Income Distribution in Italy (19771998)

Social Security and Taxation of Labour Subject to Subsidiarity and Freedom of Movement
04/02

04/02

04/02

04/02

2

1

04/02 